\title{
Consonant Discrimination and Voice Onset Time in Children with Cochlear Implants
}

\author{
Byung-Mi Park', Seong Hee Choi ${ }^{1,2,3}$, Chul-Hee Choi ${ }^{1,2,3}$ \\ ${ }^{1}$ Department of Audiology and Speech-Language Pathology, ${ }^{2}$ Research Institute of Biomimetic Sensory Control, \\ ${ }^{3}$ Catholic Hearing Voice Speech Center, Daegu Catholic University, Gyeongsan, Korea \\ 인공와우 이식 아동의 자음변별과 발성개시 시간 \\ 박병미 ${ }^{1} \cdot$ 최성희 ${ }^{1,2,3} \cdot$ 최철희 ${ }^{1,2,3}$

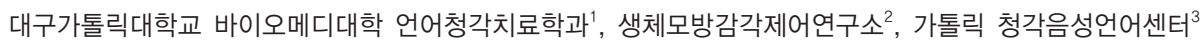

\begin{abstract}
Purpose: The present study compared the Korean consonant discrimination ability and voice onset time (VOT) between children with cochlear implants $(\mathrm{Cl})$ and children with normal hearing to investigate the characteristics of speech in children with $\mathrm{Cl}$. Methods: Twenty children with $\mathrm{Cl}$ and twenty children with normal hearing participated in the present study. Of twenty children with $\mathrm{Cl}$, ten subjects had the $\mathrm{Cl}$ surgery before three years old and the other ten subjects had after three years old. One-syllable stimuli (consonant-vowel) and twosyllable stimuli (vowel-consonant -vowel) were used to test the consonant discrimination and VOT, respectively. The consonant discrimination test was analyzed by manner of articulation (stop, fricative, affricate), place of articulation (bilabial, alveolar, palatal, velar), and voicing (lax, tense, aspirated), and VOT was analyzed by voicing. Results: For consonant discrimination, children with normal hearing showed significantly better recognition than children with $\mathrm{Cl}$ in all the consonants. For the manner of articulation, the differences were significantly highest discrimination in affricates and lowest in stops. For the place of articulation, the differences were significantly highest in palatals and lowest in bilabials. However, there was no difference based on voicing between groups. For consonant discrimination between children with $\mathrm{Cl}$ implantation before 3-years old and children with $\mathrm{Cl}$ implantation after 3-years old, there were significant differences in the manner and the place of articulation whereas no difference was found in VOT. No relationship was found between the wearing periods of $\mathrm{Cl}$ whereas age at implantation was highly correlated with consonant discrimination. For VOT, there were no significant differences in all stop sounds but the lowest discrimination was observed in stops. Conclusion: The characteristics of speech in children with $\mathrm{Cl}$ were apparent in the manner and the place of articulation but not in voicing. This was highly associated with ages of $\mathrm{Cl}$.
\end{abstract}

Key Words: Cochlear implants, Consonant discrimination, Voice onset time, Auditory training.

Received: October 2, 2017 / Revised: October 17, 2017 / Accepted: October 18, 2017

Correspondence: Chul-Hee Choi, Department of Audiology and Speech-Language Pathology, Daegu Catholic University, 13-13 Hayang-ro, Hayang-eup, Gyeongsan 38430, Korea

Tel: +82-53-850-2541 / Fax: +82-53-359-0780 / E-mail: cchoi@cu.ac.kr

\section{INTRODUCTION}

사람들은 태어나면서부터 의사소통할 수 있는 기제를 가지 고 태어나며, 성장하면서 자연스럽게 소리를 들으며 의사소통 을 하게 된다. 그러나 청각 장애 아동들은 자신의 조음기관과 발성에 문제가 없음에도 불구하고 외이로부터 대뇌에서 소리 를 이해하기까지 청각 경로에 장애를 입어 듣기에 어려움을 보 이며, 신생아기 때부터 환경으로부터 언어 자극을 제대로 받지 못하여 정상적인 음운 발달을 이루지 못한다.

건청인과 비교해 볼 때 청각 장애 아동은 다른 말소리의 특성
을 갖는다. 청각 장애 아동은 분절적인 특성으로는 모음 산출에 서의 포만트(formant)와 자음에서 파열음의 발성 개시 시간(voice onset time, VOT)에서 건청인과 다르며(Oh, 1999), 초분절적인 특성으로는 쉰 목소리와 불규칙한 높낮이, 다소 느려 빼는 운율, 부적절한 공명 등으로 왜곡된 음성을 보인다(Moon, 2003). 현재 보청기의 사용 효과가 제한되는 청각 장애 아동들에게 청능재 활을 위한 청각 보조기구로서 인공와우가 가장 많이 사용되고 있다. 즉, 보청기로 의사소통에 필요한 정보를 충분히 듣지 못 하는 고도난청을 가진 아동들에게 소리를 보다 잘 들을 수 있 도록 하기 위한 수단으로 1970년대부터 인공와우 이식이 개발 
되어 왔다. 인공와우는 신경기관인 달팽이관 역할을 인공적으 로 만들어 청각 기능을 대신하는 것이다. Woo(2006)에 의하면 음운 인식 발달의 차이가 3세 이전에 인공와우를 이식하고 청 각-구어 중심의 의사소통을 하는 6세 이상의 청각 장애 아동 은 건청 아동과 차이가 없었다고 보고했으나, 많은 선행연구들 에서는 인공와우 이식 시기가 빠를수록 건청 아동과 비슷한 음성 산출의 발달을 보이지만, 특정 연령이 지나면 건청 아동 과 다른 양상을 보인다고 보고한다(Moon, 2003; Oh, 1999).

건청 아동과 인공와우 이식 아동의 조음 특성을 비교한 선행 연구에서는 조음 방법 중 마찰음에서 인공와우 이식 아동이 건 청 보다 유의하게 높은 정확도를 보였으며, 음운 변동 비교에서 건청 아동은 긴장음화에서 유의하게 높은 출현 빈도를 보인 반 면 인공와우 이식 아동 집단은 긴장음과 대립되는 이완음화가 높은 출현 빈도를 보였다(Han et al., 2006). 한편, 전음성 청각 장애 아동과 인공와우 착용 청각 장애 아동 간의 구어 및 듣기 의 특징에 대한 연구에서는 전음성 청각 장애 아동 및 인공와 우 착용 청각 장애 아동 간 어음변별력과 어음 명료도는 차이가 없는 것으로 나타났다(Kim et al., 2006).

이러한 선행연구에도 불구하고 현재 우리나라는 효과적인 청능재활 훈련을 위한 인공와우 착용 아동들의 한국어 자음변 별 능력과 발성개시 시간의 특성에 대한 연구는 부족한 실정이 다. 본 연구는 인공와우 이식 시기에 따라 두 집단 간의 조음 방 법, 조음 위치 및 발성 유형에 따른 한국어 자음의 어음변별 능
력과 인공와우 이식 아동과 건청 아동 두 집단 간의 자음 산출 시 발성개시 특성에 대해 살펴보고자 한다. 게다가 본 연구는 인공와우 착용 기간, 청능 훈련 기간 및 인공와우 이식 연령과 자음변별력의 상관관계를 밝히고자 한다.

\section{MATERIALS AND METHODS}

\section{연구 대상}

\section{인공와우 이식 아동}

대구, 경북 지역에 거주하는 아동으로 인공와우 이식 아동 20명을 대상으로 하였다(Table 1). 인공와우 이식 아동의 선정 기준은 첫째, 인공와우 이식 아동 20명을 인공와우 이식 시기 에 따라 3 세 이전에 인공와우를 이식한 아동 10명, 3세 이후에 인공와우를 이식한 아동 10 명으로 나누어 연구를 진행하였다. 둘째, 인공와우 이식 아동은 모두 한쪽 귀에 인공와우 시술을 한 아동으로 한다. 셋째, 인공와우 이식수술 후 2년 이상 된 아 동을 대상으로 한다. 넷째, 아동은 만 6세 이상으로 글씨를 읽 을 수 있는 아동으로 한다.

인공와우 이식 시기를 3세 이전과 3세 이후로 나눈 것은 3세 이전에 인공와우를 이식하고 난 후, 6 세 이상이 된 청각 장애 아동은 청각-구어 중심의 의사소통을 하는 데 건청 아동과 음 운 인식 발달에 차이가 없다는 선행연구에 의해 나누었으며

Table 1. Information of children with $\mathrm{Cl}$

\begin{tabular}{|c|c|c|c|c|c|c|c|}
\hline Implant period & No & Last name (Gender) & Ages & Ages of CI & Wearing period of CI & Years of CI & Ears of CI \\
\hline \multirow[t]{10}{*}{ Before 3 years old } & 1 & Lee (M) & 9.9 & 1.0 & 8.9 & 2004.8 & Rt \\
\hline & 2 & $\operatorname{Kim}(\mathrm{M})$ & 7.0 & 2.3 & 4.9 & 2009.2 & Lt \\
\hline & 3 & $\operatorname{Kim}(\mathrm{M})$ & 9.2 & 1.8 & 7.7 & 2006.4 & Rt \\
\hline & 4 & Park (M) & 11.10 & 2.1 & 9.9 & 2004. 1 & Lt \\
\hline & 5 & Guan (M) & 10.0 & 2.0 & 8.0 & 2005. 11 & Rt \\
\hline & 6 & Choi (F) & 10.10 & 2.4 & 8.6 & 2005.5 & Rt \\
\hline & 7 & Lee $(\mathrm{F})$ & 8.5 & 2.3 & 6.2 & 2007. 9 & Rt \\
\hline & 8 & Shin (F) & 12.0 & 2.4 & 9.8 & 2004.3 & Rt \\
\hline & 9 & $\operatorname{Kim}(\mathrm{F})$ & 8.7 & 2.8 & 5.11 & 2007.12 & Lt \\
\hline & 10 & Kang (F) & 6.11 & 2.8 & 4.3 & 2009.8 & Rt \\
\hline \multirow[t]{10}{*}{ After 3 years old } & 11 & $\operatorname{Kim}(\mathrm{M})$ & 10.7 & 3.2 & 7.5 & 2006. 2 & Rt \\
\hline & 12 & Pun (M) & 12.6 & 6.6 & 6.0 & 2007. 11 & Lt \\
\hline & 13 & $\operatorname{Kim}(\mathrm{M})$ & 9.2 & 4.0 & 5.2 & 2008.9 & Lt \\
\hline & 14 & $\operatorname{Kim}(\mathrm{M})$ & 10 & 4.7 & 5.5 & 2007.6 & Rt \\
\hline & 15 & Jung (F) & 10.4 & 3.7 & 6.9 & 2007.2 & Rt \\
\hline & 16 & Lee $(\mathrm{F})$ & 12 & 5.8 & 6.4 & 2008.3 & Rt \\
\hline & 17 & Cho (M) & 11.2 & 4.3 & 6.11 & 2006. 12 & Lt \\
\hline & 18 & $\operatorname{Kim}(\mathrm{M})$ & 11.6 & 4.5 & 7.1 & 2006.9 & Rt \\
\hline & 19 & No (F) & 7.11 & 3.6 & 4.5 & 2009.6 & Rt \\
\hline & 20 & Park (F) & 11.7 & 5.6 & 6.1 & 2006. 10 & Rt \\
\hline
\end{tabular}

CI: cochlear implants 
(Woo, 2006), 인공와우 이식 아동의 선정기준을 인공와우 이식 후, 착용 기간을 2년 이상으로 한 것은 청각 장애 아동이 수술 을 하기 전에 보청기를 착용하고 재활 치료가 선행되었을 경우 에 수술을 받고 2 년이 경과한 후에 말을 이해하고 단어를 연결해 서 문장으로의 발화가 가능하였으며, 4년 이상 재활 치료를 하였 을 때 예후가 좋았다는 연구에 의해 제한하였다(Kim, 2009).

인공와우 이식 아동 20명 모두 인공와우 착용 후의 교정 청력 이 20 30 dB 수준이었고, 양이 인공와우는 없었으며 인공와우 반대쪽에 보청기를 착용한 아동은 남자 1명, 여자 1 명이었다.

\section{건청 아동}

대구, 경북 지역에 거주하는 아동 20명을 대상으로 하였다. 인 공와우 이식 아동과 연령을 일치시킨 만 6세 이상의 아동으로 건청 아동은 학교에서 실시한 청력선별검사에서 정상으로 보 고된 아동으로, 학교 및 유치원 선생님과 부모의 보고에 의해 읽기에 문제가 없는 아동이자 기질적 또는 기능적 장애가 없는 아동으로 하였다. 건청 아동의 연령을 만 6세 이상으로 한 이 유는 파열음의 조음 발달이 완전히 이루어졌으며, 자음변별검 사에서 검사자가 발성한 소리를 듣고 지적할 수 있으며, 파열음 의 발성개시 시작 시간을 측정함에 검사자가 제시한 파열음의 목록을 정확하게 읽을 수 있기 위해서이다.

\section{자료 수집}

아동의 발화 음성을 수집하기 위해 SONY PCM-D50 (Sony, Park Ridge, NJ, USA)을 사용하여 청각 장애 언어치료실과 유 치원 및 일반 초등학교의 조용한 빈 교실에서 녹음하였다. 녹음 시 마이크는 아동의 입으로부터 $10 \mathrm{~cm}$ 떨어진 곳에 고정하였고 녹음 시 볼륨은 5 로 고정하였다. 아동의 심리적인 긴장감을 없애 기 위해 편안한 자세로 자연스럽게 제시한 1 음절 카드를 보여주 었다.

\section{검사 도구}

\section{검사의 실시 절차 및 방법}

자음변별 확인

한국어 자음을 1 음절 수준에서 자음변별력을 평가하기 위하 여 조음 방법(파열음, 파찰음, 마찰음), 조음 위치(양순음, 치조 음, 경구개음, 연구개음) 및 발성 유형(평음, 경음, 격음)에 따른 분류에 따라 $\mathrm{CV}$ 수준에서 변별 검사를 실시하였다. 청각변별 검사를 위해 인공와우 이식 아동 및 건청 아동에게 검사자가 입 모양을 보여주지 않고 소리만 들려주는 상황(auditory only) 에서 1 음절 목록을 보여주고 들은 음절을 아동에게 찾도록 하 였다. 아동이 잘 고르지 못하는 경우는 한 번 더 입 모양을 보여 주지 않고 소리를 들려준 후 들은 음절을 찾도록 유도하였다.

검사 도구(Table 2)

평가 기준

$$
\begin{aligned}
\text { 총 자음 }(\%)= & \frac{\text { 정반응한 자음 수 }}{\text { 전체 자음 수 }} \times 100 \\
\text { 조음 방법 }(\%)= & \frac{\text { 정반응한 자음 수(파열, 파찰, 마찰) }}{\text { 전체 자음 수(파열, 파찰, 마찰) }} \times 100 \\
\text { 조음 위치 }(\%)= & \frac{\text { 조음 위치별 정반응한 자음 수(양순, 치조, 경구개, 연구개) }}{\text { 조음 위치별 전체 자음 수(양순, 치조, 경구개, , ㅕㅕㄴ구개) }} \\
& \times 100 \\
\text { 발성 유형 }(\%)= & \frac{\text { 발성 유형별 정반응한 자음 수(평음, 경음, 격음) }}{\text { 발성 유형별 전체 자음 수(평음, 경음, 격음) }} \\
& \times 100
\end{aligned}
$$

\begin{tabular}{|c|c|c|c|c|c|c|c|c|c|c|}
\hline \multirow[b]{3}{*}{ Evaluation criteria } & \multicolumn{10}{|c|}{ Test consonants } \\
\hline & \multicolumn{3}{|c|}{ Manner } & \multicolumn{4}{|c|}{ Place } & \multicolumn{3}{|c|}{ Phonation types } \\
\hline & Plosives & Affricates & Fricatives & Bilabials & Alveolar & Palatal & Velar & Lenis & Fortis & Aspirated \\
\hline \multirow[t]{9}{*}{ Test consonants } & 바, & 자, & 사, & 바, & 다, & 자, & 가, & 가, & 까, & 카, \\
\hline & 빠, & 짜, & 싸 & 빠, & 따, & 짜, & 까, & 다, & 따, & 타, \\
\hline & 파, & 차 & & 파 & 타, & 차 & 카, & 바, & 빠, & 파, \\
\hline & 다, & & & & 사, & & & 사, & 싸, & 차 \\
\hline & 따, & & & & 싸 & & & 자 & 짜 & \\
\hline & 타, & & & & & & & & & \\
\hline & 가, & & & & & & & & & \\
\hline & 까, & & & & & & & & & \\
\hline & 카 & & & & & & & & & \\
\hline
\end{tabular}

위의 공식에서와 같이 총 자음(\%)은 정답을 한 자음 수에서 제시된 전체 자음 수를 나눈 백분율이고 조음 방법(\%)은 정답을 한 파열음, 파찰음, 마찰음의 수에서 제시된 전체 파열음, 파찰 음, 마찰음의 수를 나눈 백분율을 나타낸다. 조음 위치(\%)는 정

Table 2. Consonant lists 
답을 한 양순, 치조, 경구개, 연구개음의 수에서 제시된 전체 양 순, 치조, 경구개, 연구개음의 수를 나눈 백분율을 나타내고 발 성 유형(\%)은 정답을 한 평음, 경음, 격음의 수에서 제시된 전체 평음, 경음, 격음의 수를 나눈 백분율을 의미한다.

\section{음향 음성 분석}

발성개시의 특성을 평가하기 위하여 VCV 음절 문맥에서 파 열음을 /아바/, /아빠/, /아파/, /아다/, /아따/, /아타/, /아가/, /아 까/, /아카/ 산출 시 발성개시 시간(VOT)을 측정하여 두 집단 간 차이를 비교하였다. 발성개시 시간(VOT)은 Computerized Speech Lab (CSL) 4150 B (CSL, Pentex, NJ, USA)의 스펙트 로그램 분석을 이용하여 모음-자음-모음 $(\mathrm{VCV})$ 의 음절에서 파열이 시작되는 곳부터 모음 발성이 시작되는 시간으로 측정 되었다.

\section{자료 분석 및 결과 처리}

인공와우 이식 아동과 건청 아동을 대상으로 한국어 자음의 조음 방법, 조음 위치, 및 발성 유형에 따른 두 집단 간의 자음 변별과 발성 유형에 따른 파열음의 발성개시 시간(VOT)을 분 석하기 위하여, two-way ANOVA 및 Bonferroni 사후 검정을 실시하였으며, 유의수준은 0.05 였다.

또한 VOT 측정의 평가자 간 신뢰도를 측정하기 위해 전체 피 험자 자료 중 20\%를 무작위로 선정하여 3년 이상 임상 경력을 가진 언어 장애 전문가 2명이 test-retest 검사를 실시하였으며, $86.2 \%$ 의 신뢰도를 보였다.

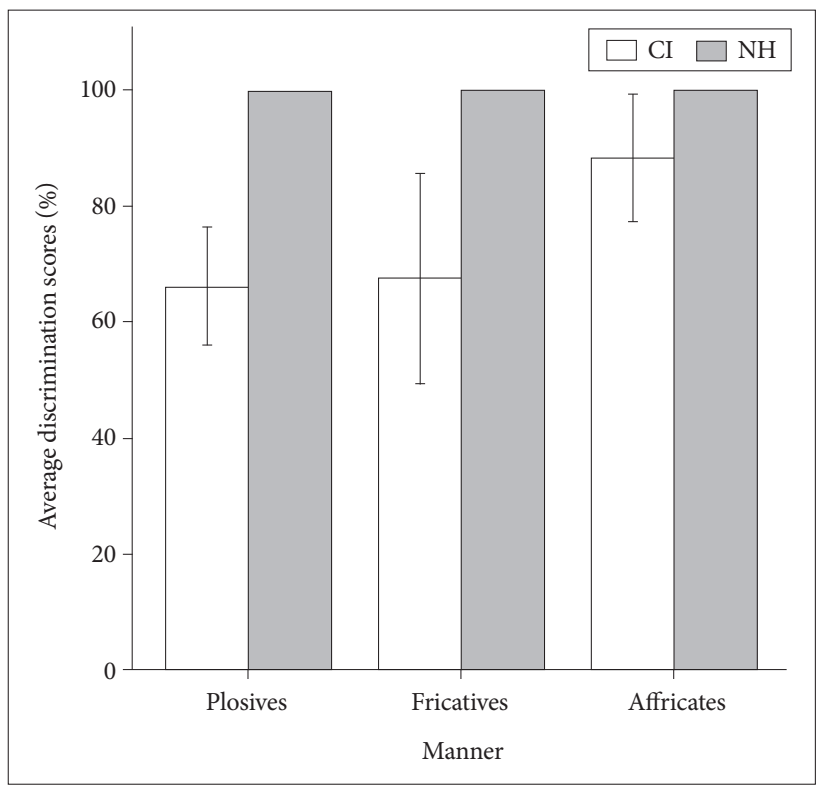

Figure 1. Average consonant discrimination in manner of articulation between children with $\mathrm{NH}$ and children with $\mathrm{Cl}$. Cl: cochlear implants, $\mathrm{NH}$ : normal hearing.

\section{RESULTS}

\section{건청 아동과 인공와우 이식 아동의 자음변별력}

건청 아동과 인공와우 이식 아동의 조음 방법에서의 자음변별력

건청 아동과 인공와우 이식 아동 집단 간 자음변별력에서 건 청 아동군은 파열음(바, 빠, 파, 다, 따, 타, 가, 까, 카), 마찰음 (사, 싸), 파찰음(자, 짜, 차) 모두 $100 \%$ 의 높은 변별력을 보였으 며, 인공와우 이식 아동군에서는 파찰음 $88.3 \%$, 마찰음 $67.5 \%$, 파열음 $66.1 \%$ 순으로 파찰음의 변별력이 가장 높았고, 파열음 의 변별력이 가장 낮았다(Figure 1).

이원분산분석 결과, 건청 아동과 인공와우 이식 아동 집단 간 자음변별력에는 통계적으로 유의한 차이가 있었으며 $[\mathrm{F}(1,114)=$ $43.59, p=0.000$ ], 조음 방법에 따라 자음변별력에 유의한 차이 를 보였다 $[\mathrm{F}(2,114)=3.33, p=0.039]$. 즉, 인공와우 이식 아동 이 건청 아동에 비해 통계적으로 낮은 자음변별력을 보였으며, 조음 방법 면에서도 파찰음이 가장 높았고, 파열음이 가장 낮 은 변별력을 나타내었다. 또한 집단과 조음 방법 간의 교호효과 도 통계적으로 유의하였다 $[\mathrm{F}(2,114)=3.33, p=0.039]$.

\section{건청 아동과 인공와우 이식 아동의 조음 위치에서의 자음변별력}

건청 아동과 인공와우 이식 아동 간 조음 위치에 따른 자음 변별 정확도에서 건청 아동은 양순음, 치조음, 경구개음 및 연구 개음에서 모두 $100 \%$ 의 자음변별력을 보였으며, 인공와우 이식 아동은 양순음 $61.66( \pm 34.7) \%$, 치조음 $62.0( \pm 24.2) \%$, 경구개

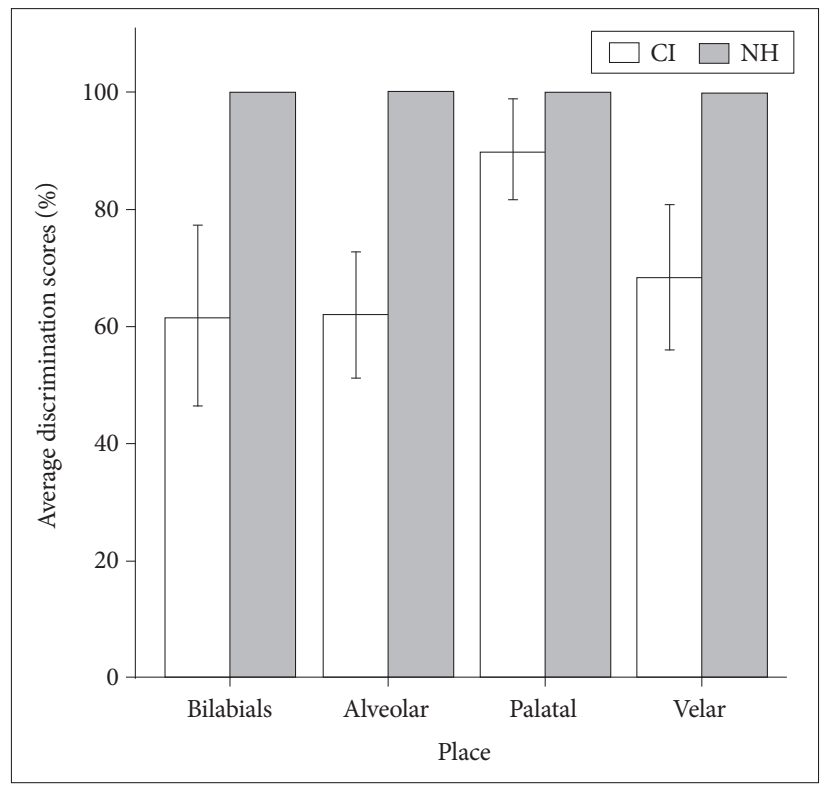

Figure 2. Average consonant discrimination in place of articulation between children with $\mathrm{NH}$ and children with $\mathrm{Cl}$. Cl: cochlear implants, $\mathrm{NH}$ : normal hearing. 
음 90.01( \pm 19.0$) \%$, 연구개음 68.35( \pm 27.5$) \%$ 로 경구개음의 자 음변별력이 가장 높았으며, 양순음의 자음변별력이 가장 낮았다 (Figure 2).

이원분산분석 결과, 건청 아동과 인공와우 이식 아동 집단 간 자음변별력에서 통계적으로 유의한 차이가 있었으며 $[\mathrm{F}(1,152)=$ 95.75, $p=0.000]$, 조음 위치에 따른 자음변별력에서도 유의한 차이를 보였다 $[\mathrm{F}(3,152)=4.910, p=0.03]$. 즉, 건청 아동은 $100 \%$ 의 자음변별력을 보인 반면, 인공와우 이식 아동은 건청 아동에 비 해 여전히 낮은 자음변별력을 보였다 $(p=0.003)$. Bonferroni 사 후검정에 의한 다중 비교 결과, 양순음과 경구개음 $(p=0.007)$, 치조음과 경구개음 $(p=0.008)$ 에서 유의한 차이가 있는 것으로 나타났다. 또한 집단과 조음 위치 간의 교호효과도 통계적으로 유의하였다 $[\mathrm{F}(3,152)=4.910, p=0.003]$.

건청 아동과 인공와우 이식 아동의 발성 유형에서의 자음변별력

건청 아동과 인공와우 이식 아동 집단 간 자음변별력에서 건 청 아동은 발성 유형에 따른 평음, 경음, 격음 모두 $100 \%$ 의 높은 변별력을 보였으며, 인공와우 이식 아동은 격음 $75 \%$, 평음 $67 \%$, 경음 $65 \%$ 순으로 격음이 $75 \%$ 로 가장 높은 변별력을 보였다

(Figure 3).

이원분산분석 결과, 건청 아동과 인공와우 이식 아동 집단 간 자음변별력에는 통계적으로 유의한 차이가 있었으며 $[\mathrm{F}(1,114)=$ 69.602, $p=0.000]$, 발성 유형에 따라 자음변별력에 유의한 차이 를 보이지 않았다 $[\mathrm{F}(2,114)=0.676, p=0.511]$. 또한 집단과 발 성 유형 간의 교호효과도 통계적으로 유의하지 않았다 $[\mathrm{F}(2,114)$ $=0.676, p=0.511]$.

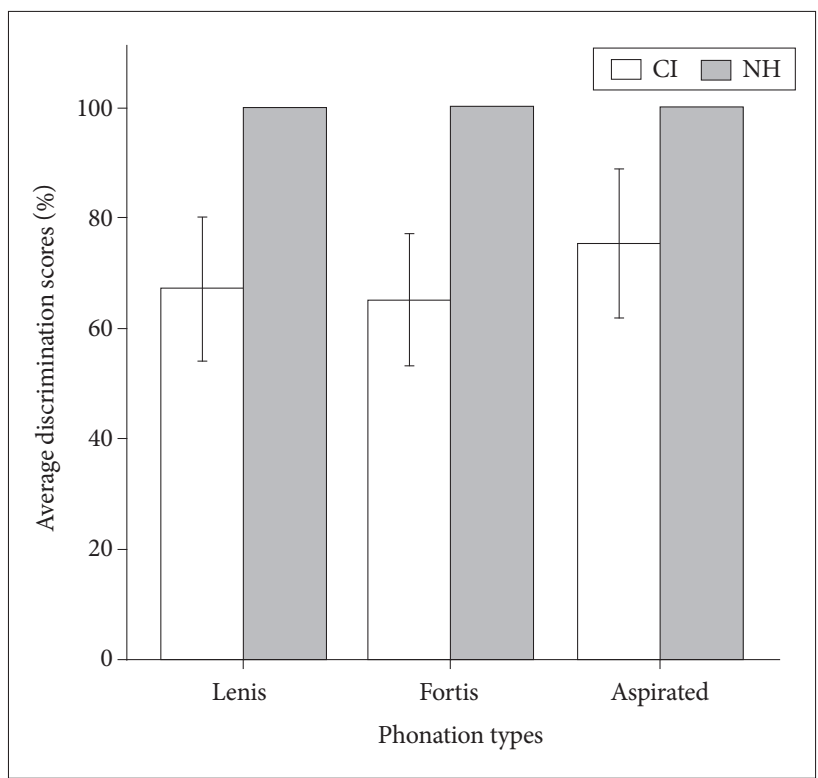

Figure 3. Average consonant discrimination in phonation types between children with $\mathrm{NH}$ and children with $\mathrm{Cl}$. Cl: cochlear implants, $\mathrm{NH}$ : normal hearing.

\section{3세 이전과 3세 이후 인공와우 이식 아동의 자음변별력}

3세 전후 인공와우 이식 아동 집단 간 조음 방법에 따른 자음 변별력

3세 이전과 3세 이후 인공와우 이식 아동 집단 간 조음 방법 에 따른 자음변별력에서 3 세 이전 인공와우 이식 아동 집단의 자 음변별력은 파열음 $77.80( \pm 14.80) \%$, 마찰음 90.00( \pm 21.08$) \%$, 파찰음 $96.67 \pm 10.53) \%$ 로 파찰음의 자음변별력이 $100 \%$ 에 가 깝게 근접하였으며, 파열음은 $80 \%$ 정도의 변별력을 보였다. 반 면에 3세 이후 인공와우 이식 아동 집단은 역시 파찰음의 변별 력이 80.01( \pm 32.20$) \%$ 로 가장 높았으나, $80 \%$ 정도의 변별력을 보였으며 파열음의 변별력은 54.44( \pm 24.28$) \%$ 로 $50 \%$ 수준의 낮은 변별력을 나타내었다(Figure 4).

이원분산분석 결과, 3 세 전후 인공와우 이식 아동 집단 간 자음변별력에는 통계적으로 유의한 차이가 있었으며 $[\mathrm{F}(1,54)=$ $16.74, p=0.000]$, 조음 방법에 따라 자음변별력에 유의한 차이 를 보였다 $[\mathrm{F}(2,54)=4.31, p=0.018]$. Bonferroni 사후 검정에 의한 다중 비교 결과, 조음 방법에 따라 파열음과 파찰음 간에 는 유의한 차이를 보였다 $(p=0.034)$. 즉, 3 세 이전 인공와우 이 식 아동은 파찰음 $96.7 \%$, 마찰음 $90 \%$, 파열음 $77.8 \%$ 의 순으로 파찰음의 변별력이 가장 높았으며, 3세 이후 인공와우 이식 아 동은 파찰음 $80 \%$, 파열음 $54.4 \%$, 마찰음 $45 \%$ 의 순으로 3세 이 전과 3세 이후 인공와우 이식 아동 모두 파찰음의 변별력이 가 장 높았다. 또한 집단과 조음 방법 간의 교호효과도 통계적으로 유의한 차이를 보이지 않았다 $[\mathrm{F}(2,54)=1.53, p=0.227]$.

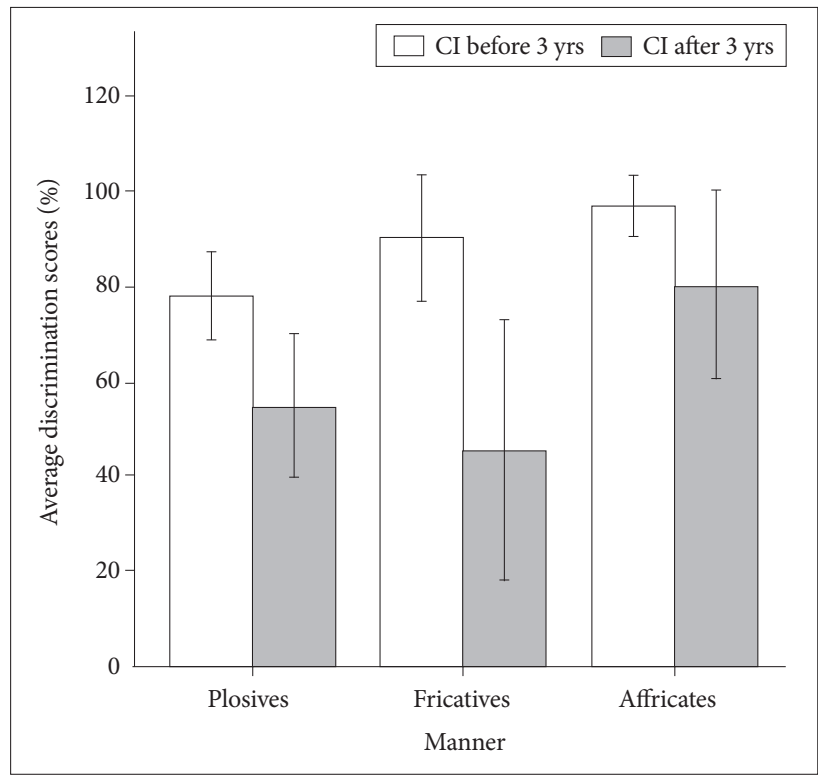

Figure 4. Average consonant discrimination in manner of articulation between children with $\mathrm{Cl}$ before 3 years old and children with $\mathrm{Cl}$ after 3 years old. Cl: cochlear implants. 


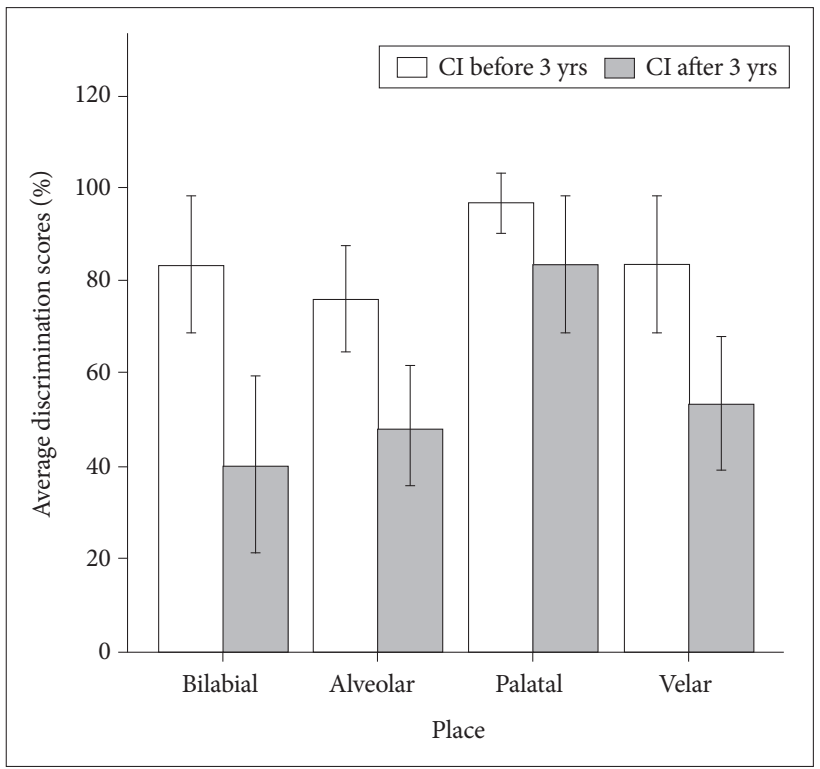

Figure 5. Average consonant discrimination in place of articulation between children with $\mathrm{Cl}$ before 3 years old and children with $\mathrm{Cl}$ after 3 years old. $\mathrm{Cl}$ : cochlear implants.

3세 전후 인공와우 이식 아동 집단 간 조음 위치에 따른 자음 변별력

3세 전후 인공와우 이식 아동 집단 간 조음 위치에 따른 자 음변별 정확도에서 3세 이전 인공와우 이식 아동은 경구개음 $96.67 \%$, 연구개음 $83.34 \%$, 양순음 $83.34 \%$, 치조음 $76 \%$ 의 순으 로 경구개음의 변별력이 가장 높았으며, 3세 이후 인공와우 이 식 아동은 경구개음 $83.34 \%$, 연구개음 $53.35 \%$, 치조음 $48 \%$, 양 순음 39.99\%의 순으로 3세 전후 인공와우 이식 아동은 경구개 음의 변별력이 가장 높았다(Figure 5).

통계분석의 결과, 3 세 전후 인공와우 이식 아동 집단 간 자음 변별력에는 통계적으로 유의한 차이가 있었으며 $[\mathrm{F}(1,72)=32.38$, $p=0.000], 3$ 세 이전 인공와우 이식 아동이 3세 이후 인공와우 이식 아동에 비해 자음변별력이 통계적으로 유의하게 높았다. 또 한, 조음 위치에 따라 자음변별력에 통계적으로 유의한 차이를 보였다 $[\mathrm{F}(3,72)=7.032, p=0.000]$. Bonferroni 사후 검정에 의한 다중 비교 결과, 조음 위치에 따라 경구개음과 양순음 $(p=0.001)$, 경구개음과 치조음 $(p=0.001)$, 경구개음과 연구개음 간에는 유 의한 차이를 보였다 $(p=0.020)$. 또한 집단과 조음 위치 간의 교 호효과는 통계적으로 유의한 차이를 보이지 않았다 $[\mathrm{F}(3,72)=$ $1.487, p=0.225]$.

3세 전후 인공와우 이식 아동 집단 간 발성 유형에 따른 자음 변별력

3세 이전 인공와우 이식 아동과 3세 이후 인공와우 이식 아 동 집단 간 자음변별력에서 3세 이전 인공와우 이식 아동은 평 음 $86( \pm 16.47) \%$, 경음 $82( \pm 14.76) \%$, 격음 $80( \pm 25.82) \%$ 의 높

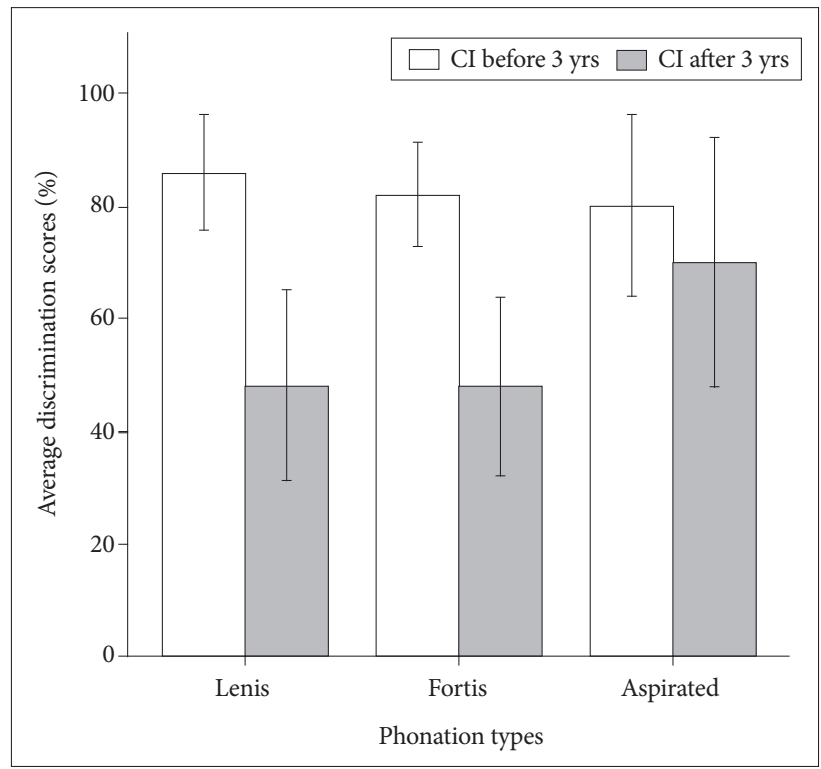

Figure 6. Average consonant discrimination in phonation types between children with $\mathrm{Cl}$ before 3 years old and children with $\mathrm{Cl}$ after 3 years old. $\mathrm{Cl}$ : cochlear implants.

은 변별력을 보였으며, 3세 이후 인공와우 이식 아동은 격음이 70 ( \pm 34.96)\%로 가장 높은 변별력을 보였다(Figure 6).

이원분산분석 결과, 3 세 전후 인공와우 이식 아동 집단 간 자음변별력에는 통계적으로 유의한 차이가 있었으나 $[\mathrm{F}(1,54)=$ $17.947, p=0.000]$, 발성 유형에 따른 자음변별력에는 유의한 차 이를 보이지 않았다[F(2,54) $=0.897, p=0.414]$. 즉, 3 세 이전 인공 와우 이식 아동이 3세 이후 인공와우 이식 아동에 비해 발성 유 형에 따른 자음변별력이 높았으나, 발성 유형에 따른 평음, 경음, 격음 간 자음변별력의 차이는 없었다. 또한 집단과 조음 위치 간 의 교호효과는 통계적으로 유의한 차이를 보이지 않았다 $[\mathrm{F}(2,54)$ $=1.836, p=0.169]$.

\section{인공와우 착용 기간, 청능 훈련 기간 및 인공와우 이식 연령과 자음변별력과의 관계 분석}

\section{인공와우 착용 기간과 자음변별력의 상관관계}

인공와우 착용 기간과 자음변별력 관계 분석에서 인공와우 착용 기간과 자음변별력 간의 상관계수 $r=0.259$ 로 인공와우 착 용 기간과 자음변별력 사이에는 유의하지 않았다 $(p=0.270)$. 즉, 인공와우를 오랜 기간 착용했다고 해서 높은 자음변별력을 나 타내지 않았다.

\section{인공와우 이식 연령과 자음변별력의 상관관계}

인공와우 이식 연령과 자음변별력 관계 분석에서 인공와우 이식 연령과 자음변별력 간의 상관계수 $\mathrm{r}=-0.681$ 로 높은 부적 상관관계를 보였다 $(p=0.001)$. 즉, 이식 연령이 빠를수록 높은 


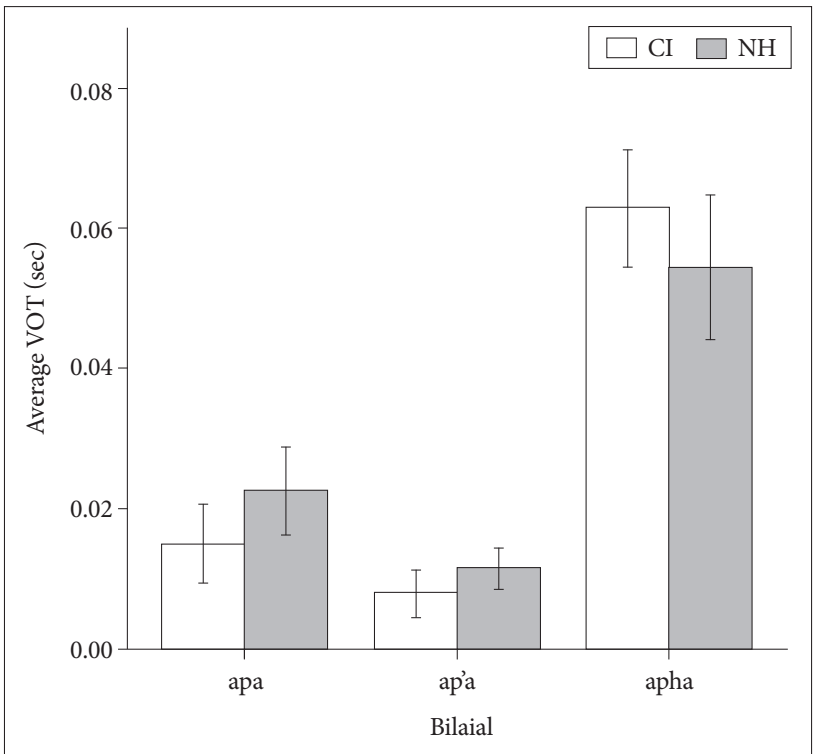

Figure 7. Average consonant discrimination in phonation types of bilabial stops between children with $\mathrm{NH}$ and children with $\mathrm{Cl}$. Cl: cochlear implants, $\mathrm{NH}$ : normal hearing, VOT: voice onset time.

자음변별력을 나타내었다.

\section{청능훈련 기간과 자음변별력의 상관관계}

청능 훈련 기간과 자음변별력 관계 분석에서 청능 훈련 기간 과 자음변별력 간의 상관계수 $r=0.314$ 로 인공와우 이식 아동의 청능 훈련 기간과 자음변별력 사이에는 유의하지 않았다 $(p=$ 0.178). 그러나 7년까지는 청능 훈련 기간이 증가함에 따라 자음 변별력이 증가하는 패턴을 보였으나, 8년과 9년에는 약간 감소 된 경향을 보였다.

\section{발성 개시 시간}

건청 아동과 인공와우 이식 아동의 양순 파열음 VOT 비교

건청 아동과 인공와우 이식 아동의 양순 파열음 VOT에서 건청 아동의 경우, 아바 $0.0250( \pm 0.01342)$ 초, 아빠 $0.0115( \pm$ $0.00671)$ 초, 아파 $0.0545( \pm 0.02328)$ 초로 '아파'가 가장 길게 나 타났으며, 인공와우 이식 아동의 경우, 아바, 아빠, 아파는 각각 $0.0115( \pm 0.0142)$ 초, $0.0080( \pm 0.00768)$ 초, $0.0630( \pm 0.01895)$ 초 로 건청 아동과 마찬가지로 "아파가 가장 길었다(Figure 7).

이원분산분석 결과, 건청 아동과 인공와우 이식 아동 집단 간 양순 파열음의 VOT에는 통계적으로 유의한 차이가 없었으 며 $[\mathrm{F}(1,114)=0.041, p=0.841]$, 발성 유형에 따라 양순 파열음의 VOT에는 유의한 차이를 보였다[F(2,114) $=173.250, p=0.000]$. Bonferroni 사후 검정에 의한 다중 비교 결과, / 아바/와 / 아파/, /아빠/와 / 아파/ 간에는 유의한 차이를 보였다 $(p=0.000)$. 또한 집단과 양순 파열음 $\mathrm{VOT}$ 간의 교호효과는 통계적으로 유의한

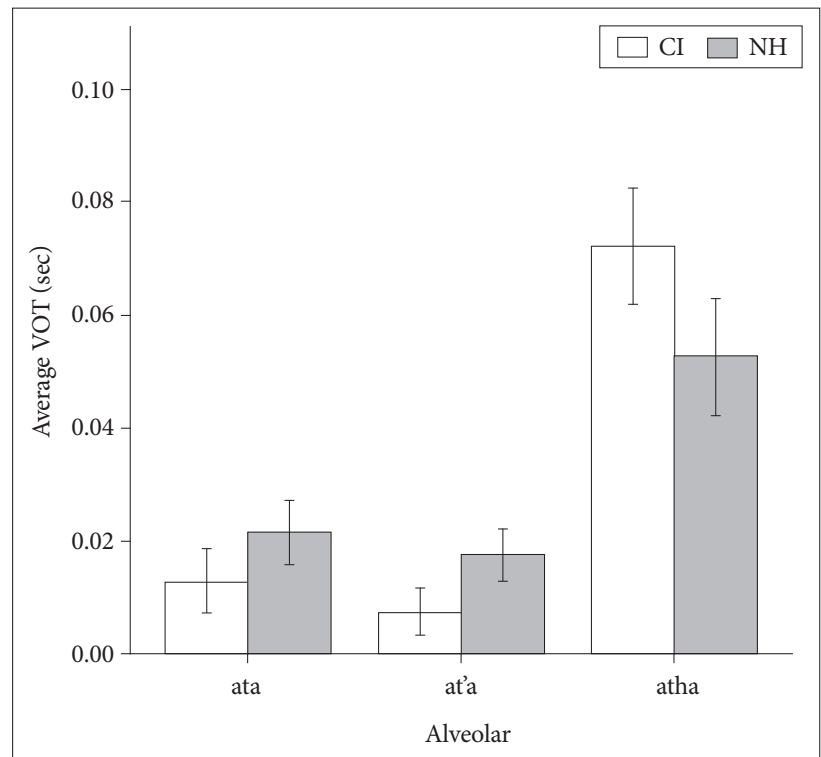

Figure 8. Average consonant discrimination in phonation types of alveolar stops between children with $\mathrm{NH}$ and children with $\mathrm{Cl}$. $\mathrm{Cl}$ : cochlear implants, $\mathrm{NH}$ : normal hearing, VOT: voice onset time.

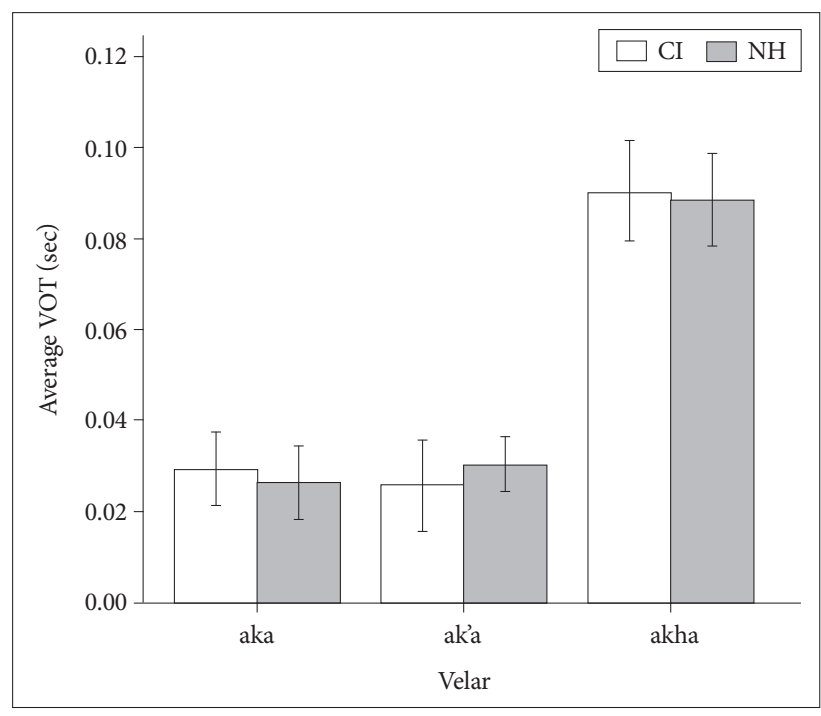

Figure 9. Average consonant discrimination in phonation types of soft palate stops between children with $\mathrm{NH}$ and children with $\mathrm{Cl}$. $\mathrm{Cl}$ : cochlear implants, $\mathrm{NH}$ : normal hearing, VOT: voice onset time.

차이를 보이지 않았다 $[\mathrm{F}(2,114)=2.598, p=0.079]$.

건청 아동과 인공와우 이식 아동의 치조 파열음 VOT 비교

건청 아동과 인공와우 이식 아동의 치조 파열음 $\mathrm{VOT}$ 에서 건청 아동의 경우, 아다 0.0215( \pm 0.01268)초, 아따 0.0175( \pm $0.01020)$ 초, 아타 $0.0525( \pm 0.02314)$ 초로, '아타'가 가장 길게 나 타났으며, 인공와우 이식 아동의 경우, 아다, 아따, 아타는 각각 0.0130( \pm 0.01261)초, 0.0075( \pm 0.00910)초, $0.0720( \pm 0.02308)$ 초로 건청 아동과 마찬가지로 "아타가 가장 길었다(Figure 8). 이원분산분석 결과, 건청 아동과 인공와우 이식 아동 집단 
간 치조 파열음의 VOT에는 통계적으로 유의한 차이가 없었으 며 $[\mathrm{F}(1,114)=0.013, p=0.910]$, 발성 유형에 따라 치조 파열음의 VOT에는 유의한 차이를 보였다[F(2,114) $=114.880, p=0.000]$. Bonferroni 사후 검정에 의한 다중 비교 결과, 치조 파열음의 VOT는 / 아다/와 / 아타/, / 아따/와 / 아타/ 간에는 유의한 차이를 보였다 $(p=0.000)$. 또한, 집단과 치조 파열음 VOT 간의 교호효 과는 통계적으로 유의한 차이를 보였다 $[\mathrm{F}(2,114)=10.519, p=$ 0.000].

\section{건청 아동과 인공와우 이식 아동의 연구개 파열음 VOT 비교}

건청 아동과 인공와우 이식 아동의 연구개 파열음 VOT에서 건청 아동의 경우, 아가 $0.0265( \pm 0.01814)$ 초, 아까 0.0305 ( \pm 0.01317)초, 아카 $0.0885( \pm 0.02300)$ 초로, '아카'가 가장 길게 나 타났으며, 인공와우 이식 아동의 경우, 아가, 아까, 아카는 각각 0.0295( \pm 0.01791)초, 0.0260( \pm 0.02257)초, 0.0905( \pm 0.02544) 초로 건청 아동과 마찬가지로 '아카'가 가장 길었다(Figure 9).

이원분산분석 결과, 건청 아동과 인공와우 이식 아동 집단 간 연구개 파열음의 $\mathrm{VOT}$ 에는 통계적으로 유의한 차이가 없었 으며 $[\mathrm{F}(1,114)=0.002, p=0.964]$, 발성 유형에 따라 연구개 파열 음의 VOT에는 유의한 차이를 보였다 $[\mathrm{F}(2,114)=120.100, p=$ 0.000]. Bonferroni 사후 검정에 의한 다중 비교 결과, 연구개 파 열음의 VOT는 / 아가/와 / 아카/, / 아까/와 / 아카/ 간에 유의한 차 이를 보였다 $(p=0.000)$. 또한 집단과 연구개 파열음 $\mathrm{VOT}$ 간의 교호효과는 통계적으로 유의한 차이를 보이지 않았다 $[\mathrm{F}(2,114)$ $=0.397, p=0.674]$.

\section{DISCUSSIONS}

본 연구는 인공와우 이식 아동과 건청 아동의 자음변별 능 력과 발성개시 시간(VOT)을 알아보고 인공와우 이식 아동을 이식 시기에 따라 3세 이전과 3세 이후로 구분하여 자음변별력 과 발성개시 특성을 비교분석하였다.

\section{자음변별력의 비교}

조음 위치에서의 자음변별력을 비교분석하면, 건청 아동은 파열음, 마찰음, 파찰음에서 모두 높은 변별력을 보였지만 인공 와우 아동은 파찰음, 마찰음, 파열음 순으로 비교적 낮은 변별 력을 보였다. 보청기 착용아와 인공와우 착용아의 어음변별력 과 어음명료도의 상관관계를 조사한 다른 연구에서는 보청기 착용아는 단어 수준에서 어음변별력은 파열음, 파찰음, 마찰음, 비음 순으로 오류가 많았고, 단어 수준에서 어음변별력은 파열 음, 파찰음, 비음, 마찰음 순으로 오류가 많아 본 연구와 마찬가 지로, 파열음 변별이 가장 어려운 것으로 나타났다(Ju, 2005).
인공와우를 이식한 아동의 전체 집단은 경구개음, 연구개음, 치조음, 양순음 순으로 변별력이 높았고, 3 세 전후 인공와우 이 식 아동 집단 간 자음변별력에는 통계적으로 유의한 차이를 보 였다. 3 세 이전에 인공와우를 이식한 아동 집단은 경구개음, 양 순음, 연구개음, 치조음 순으로, 3 세 이후에 인공와우를 이식한 아동 집단은 경구개음, 연구개음, 치조음, 양순음 순으로 변별력 이 높았다. 본 연구의 결과는 인공와우 이식 아동은 경구개음을 가장 잘 변별하는 결과를 보여 시각적인 단서를 보여주는 자음 이 일찍 발달한다는 것과는 대조적이나, $\operatorname{Kim}(2009)$ 의 선행연구 에서 경구개음이 가장 높은 변별을 보인 결과와는 일치하였다.

조음 방법에서의 자음변별력은 인공와우를 이식한 아동의 전체 집단은 파찰음, 마찰음, 파열음의 순으로, 3 세 이전에 인 공와우를 이식한 아동은 파찰음, 마찰음, 파열음의 순으로 3세 이후에 인공와우를 이식한 아동은 파찰음, 파열음, 마찰음의 순으로 자음변별력이 높은 것으로 보여, 파찰음을 가장 잘 변 별하는 결과를 나타내었다. 3 세 전후 인공와우 이식 아동 집단 간 자음변별력에는 통계적으로 유의한 차이가 있었으며, 본 연 구의 조음 방법에서의 연구 결과는 Owens(1978)의 파열음과 마찰음이 자음 중 청각 장애인이 가장 지각하기 어려운 음소라 고 한 선행연구와 $\operatorname{Kim}(2002)$ 의 연구에서 조음 방법에 따른 변 별 오류 특성 중에 파찰음이 가장 낮게 나타났으며, 마찰음과 파열음이 가장 높게 나타난 선행연구와는 일치하였다.

발성 유형에서의 자음변별력은 인공와우 이식 아동의 전체 집단은 격음, 평음, 경음 순으로 변별력을 보였고, 3세 이전에는 평음, 경음, 격음의 순으로 3 세 이후에는 격음, 평음과 경음이 같은 결과를 보였다.

3세 이전에 인공와우를 이식한 아동과 3 세 이후에 인공와우 를 이식한 아동 간에는 3 세 이전에 인공와우 이식을 한 아동 집단이 높은 자음변별력을 보였으며, 조음 위치에서는 경구개음 과 양순음, 경구개음과 치조음, 경구개음과 연구개음 간에는 유 의한 차이를 보였다. 또한 조음 방법에서는 파열음과 파찰음의 경우 유의한 차이를 보였다.

자음변별의 정확도는 인공와우의 스펙트럼 채널의 수에 따 라 다름을 보고하였다. Xu et al.(2002)은 모음과 자음 및 문장 인식 과제를 최적으로 수행하기 위해서는 최소한 6개의 스펙트 럼의 채널이 요구된다고 하였으며, Lin et al.(2009)은 자음 인 식은 16채널까지는 변별 능력이 증가하다가 16 이상부터는 자 음 인식에 차이를 보이지 않는다고 하여 적절한 인공와우 스펙 트럼의 수를 제안하였다. 따라서 인공와우의 스펙트럼 채널 수 를 증가시킴으로써 자음 인식 능력을 증가시킬 수 있음을 시사 하였다. 본 연구 참여자들은 각기 다른 인공와우 채널의 수를 가지고 있으며, 이러한 것이 자음변별력에 영향을 미칠 수 있을 것이다. 또한, 인공와우 착용인들은 청신경의 직접적인 전기적 
자극으로 청각 능력(audibility)이 개선되어 향상된 말 지각 능 력을 보임에도 불구하고 획득된 청력에 비하여 말 지각 능력이 횔씬 못 미치는 경향이 있는데, 이러한 이유 중 하나로 Jang et al.(2007)은 말 지각의 어려움이 인공와우를 통한 청각적 정보 의 열악한 spectral 및 temporal resolution 등의 요소에 기인한 다고 하였다. Lin et al.(2009)도 1) 파열음과 마찰음의 포만트 전이, 2) 파열음, 마찰음 및 파찰음의 소음 스펙트럼, 3) 마찰음의 스펙트럼의 정점(peak) 등 이외에 다른 음향학적 자질(침묵 기 간, 발성개시 시간, 소음 지속 기간 등)이 인공와우 착용자들의 자음 인식과 변별에 영향을 준다고 하였다. 본 연구에서 파열음 의 지각이 가장 낮은 이유는 파열음 산출의 음향학적 단서를 제 공하는 포만트 전이 및 막음, 침묵 기간, 발성개시 시간 등에 대 한 청각적 피드백 정보가 여전히 부족함에 기인한 것으로 보인 다. 반면에, 파찰음은 파열음이나 마찰음에 비해 막음, 지속, 지 연 개방 등 파열과 마찰의 정보를 함께 가지고 있어서 이러한 음향학적 특성들이 파찰음이 가장 높은 자음변별력을 나타내 는 데 도움을 준 것으로 추측된다.

또한 조음 위치 면에서 볼 때, 양순음의 경우 다른 조음 위치에 비해 에너지 분포가 최저이며, 약 $600 \mathrm{~Hz}$ 이하에 에너지 정점이 형성되고, 치경음은 에너지 분포가 중간 정도이며 에너지 정점 이 3,000 Hz에서 형성되는 반면, 구개음은 다른 조음 위치와 비 교하여 에너지 분포가 가장 높으며 600 3,000 Hz 사이에 에너 지 정점이 형성되므로(Ferrand, 2006) 인공와우 이식 아동의 경 우 구개음의 자음변별이 다른 조음 위치에 비해 비교적 쉬울 것 으로 생각된다. 또한, 파열음의 자음변별이 가장 낮은 이유로 Roman et al.(2004)은 뇌간 청각유발전위검사를 이용하여 파열음 자음변별을 연구하였는데, 인공와우 이식자나 건청인 모두 VOT와 같은 temporal cue (시간적 단서)를 파열음을 변별하는 데 사용하였으나, 청각 임시적 처리 능력이 건청인에 비해 인공 와우 이식자들이 떨어짐을 보고하여 이러한 차이가 인공와우 이식자들의 파열음 변별 능력에 영향을 주는 것으로 보았다.

본 연구에서는 이식 시기가 빠를수록 어음변별력이 높다는 많은 선행연구와 동일하게 3세 이전에 인공와우를 이식한 집단 이 3세 이후에 인공와우를 이식한 집단에 비해 조음 위치, 조 음 방법, 발성 유형에서 높은 변별력을 보였다.

인공와우 착용 기간과 자음변별력에서는 인공와우 착용 기간 과 자음변별력 사이는 유의하지 않았다. 즉 인공와우를 오랜 기 간 착용했다고 해서 높은 자음변별력을 나타내지 않았다. 이러 한 결과는 자음변별 능력이 인공와우 착용 기간보다는 인공와 우 이식 시기와 청능 훈련에 영향을 받는 것으로 볼 수 있을 것 이다. 따라서, 임상적으로 인공와우 착용 기간보다는 인공와우 이식 시기가 의사소통을 위한 자음변별력에 더 큰 도움을 줄 수 있음을 시사하였다.
또한 청능 훈련 기간에 따라 자음변별력을 비교해 보았을 때, 본 연구에서는 청능 훈련 기간이 길어질수록 높은 자음변별력 을 보였으나, 청능 훈련 기간 8 9년에는 자음변별력이 약간 감 소하는 경향을 보였다. 이러한 연구결과는 인공와우 이식수술 후 기간이 경과할수록 점차 청각적 정보를 와우를 통해 받아들 이는 처리 능력이 더 정교해지며 안정화되어지므로 나타나는 결 과라고 볼 수 있다. 또한, 청능 훈련 기간이 2년부터 7년까지 청 능 훈련 기간이 증가할수록 자음변별력이 증가하는 패턴을 보 여 청능 훈련이 자음변별에 중요한 영향을 줄 수 있음을 시사하 였다. 그러나 이들이 받은 청능 훈련의 내용은 개인차가 있었으 며, 일반적으로 환경음과 말소리 구별, 모음과 자음의 변별력에 대한 분절적 요소에 대한 훈련으로 초분절적 요소에 대한 청능 훈련은 부재하였다. 따라서 의사소통에서 말소리가 감정이나 상 황에 따라 억양이나 강세, 음높이 등이 달라지는 것을 감안할 때, 음도, 강도, 음질 등에 대한 초분절적 요소에 대한 훈련도 매 우 중요할 것으로 사료된다. 그러나 인공와우 이식 아동은 개인 적인 차이가 많으며, 부모나 주위 환경, 인공와우 착용 전의 언 어능력, 잔존 청력 등 복합적 요인이 영향을 미치는 것으로 나 타났다.

\section{발성개시 시간}

인공와우 이식 아동과 건청 아동 집단 간 양순 파열음 $\mathrm{VOT}$ 에서는 /아바/, /아빠/, /아파/의 경우 모두 유의한 차이를 보이 지 않았으나, 발성 유형에 따라 양순 파열음 / 아바/와 /아파/, /아빠/와 / 아파/ 간에는 유의한 차이를 보였다. 3 세 전후 인공 와우 이식 아동 집단 간에도 유의한 차이를 나타내지 않았다.

인공와우 이식 아동과 건청 아동 집단 간 치조 파열음 $\mathrm{VOT}$ 에서는 /아다/, /아따/, /아타/의 경우 유의한 차이를 보이지 않 았으나, 발성 유형에 따라 치조 파열음의 VOT에는 유의한 차 이를 보였다. 치조 파열음의 VOT에 따라 /아다/와 /아타/, /아 따/와 /아타/ 간에는 유의한 차이를 보였다. 3세 이전 인공와우 이식 아동과 3 세 이후 인공와우 이식 아동 집단 간에는 유의한 차이를 나타내지 않았다.

인공와우 이식 아동과 건청 아동 집단 간 연구개 파열음 $\mathrm{VOT}$ 에서는 /아가/, /아까/, /아카/의 경우 모두 유의한 차이를 보이 지 않았으나, 발성 유형에 따라 연구개 파열음의 VOT에는 유 의한 차이를 보였다, 즉 / 아가/와 / 아카/, / 아까/와 /아카/ 간에 는 유의한 차이를 보였다. 3세 이전 인공와우 이식 아동과 3세 이후 인공와우 이식 아동 집단 간에도 유의한 차이를 나타내 지 않았다. Shin \& Seok(2006)의 청각 장애 아동과 건청 아동 의 어두 파열음의 VOT 지각 비교연구에서 두 집단 간 조음 위 치별 지각 형태 즉, 양순 파열음, 치조 파열음, 연구개 파열음에 서 청각 장애 아동은 건청 아동과 유사하게 나타났으나, 청각 
장애 아동이 건청 아동에 비해 가변성이 높았다. 본 연구에서 도 건청 아동 집단과 인공와우 이식 아동 집단 간의 파열음 $\mathrm{VOT}$ 를 비교분석한 결과 두 집단 간의 양순 파열음, 치조 파열 음, 연구개 파열음에서는 유의한 차이가 없었다. 이러한 결과는 청각 장애 아동은 파열음의 VOT는 지각이나 산출에서 건청 아동과 유사한 패턴을 따르고 있음을 시사한다.

파열음을 발성 유형에 따라 평음, 경음, 격음으로 분류하고 VOT를 비교해 보면, 건청 아동 집단과 인공와우 이식 아동 집 단 모두 경음, 평음, 격음의 순으로 VOT가 길게 나타났으며, 조 음 위치별 VOT에서도 양순음, 치조음, 연구개음으로 VOT가 길어지는 결과를 보였다. 본 연구 결과는 Chae(1997) 연구에서 파열음의 VOT를 측정한 결과 경음, 평음, 격음의 순으로 VOT 가 길어지며, 조음 위치별 VOT에서도 양순음, 치조음, 연구개음 으로 연구개음에서 VOT가 가장 길었다는 선행연구와 일치하 게 나타났다. 또한, Hardcastle(1973)의 연구에서 파열음의 공기 역학적 특성과 음향학적 특징을 성대와 후두의 긴장성 자질 측 면에서 연구한 선행연구에서 보인 평음에 비해 격음이 2 3.5배 더 길고, 연구개음의 $\mathrm{VOT}$ 가 치조음과 양순음에 비해 더 길다 는 선행연구와 일치하였다. 연구개 파열음이 양순음, 치조음에 비해 길어지는 이유는 폐쇄 개방 이후 후행 모음까지 걸리는 시 간이 양순음이나 치조음에 비해 혀의 움직임이 느리게 진행되고 기류가 빠져나오는 시간이 길어지기 때문이라고 볼 수 있을 것이 다. 또한 파열음의 경음과 격음은 조음 방법에 있어서 평음과 같 으나, 기류의 세기에서 차이가 나타나는 소리로 경음은 공기를 내보낼 때 조음기관을 긴장시켜 터뜨리고, 격음은 구강 안에 공 기를 가두어 압축시켰다가 세게 터트려야 한다. 그러므로 성대 의 긴장과 성문의 크기와 관련이 있어 기류를 많이 내보내야 하 는 격음의 VOT가 가장 길어질 수 있다고 볼 수 있을 것이다.

본 연구에서는 두 집단 간 VOT 산출에는 통계적으로 유의 하지 않았으나, 파열음을 인식하는 능력은 인공와우 이식 아동 이 저하되어 있는 것으로 나타나, 인공와우 이식 아동들은 $\mathrm{VOT}$ 와 같은 시간적 단서를 인식하는 청각능력이 여전히 저하 되어 있음을 간접적으로 나타내었다. 본 연구에서 VCV 수준에 서 파열음 산출의 정확도는 측정하지 않았으나, VOT 산출이 격음 > 평음 > 격음 순으로 건청 아동과 유사한 패턴을 보였 으며, 건청 아동과 인공와우 이식 아동 간에 통계적으로 유의 한 차이를 보이지 않았다. 또한 선행연구에 의하면, 청각 장애 아동들이 마찰음이나 파찰음에 비해 비교적 파열음 산출의 정 확도가 높다고 하였지만(Lee, 1999) 본 연구에서는 자음 지각 에 있어서 파열음 변별이 가장 낮아 인공와우 이식 아동에게 있어서 파열음 산출과 인식은 다른 처리 과정임을 시사하였다. 또한 본 연구에서는 VOT를 이용한 산출과 지각 실험은 이루
어지지 않았으나, 인공와우 이식 아동이 여전히 파열음 지각이 어려운 점을 감안할 때, VOT와 같은 파열음의 음향학적 단서 를 청각적 정보로 적절히 이용할 수 있는 청능 재활훈련이 필요 함을 시사한다.

중심 단어 : 인공와우·자음변별·발성개시 시간·청능 훈련.

\section{REFERENCES}

Chae, Y. J. (1997). Comparative Study of Korean and French Stops (unpublished master's thesis). Chonbuk National University, Jeonju.

Han, J. H., Kim, H. H., Pae, S. Y., \& Shin, J. C. (2006). A comparison of phonological process between normal children and children with cochlear implants. Communication Sciences and Disorders, 11(2), 56-71.

Hardcastle, J. I. (1973). The phonetics and phonological of "Tens" and "Plain" consonants in Korean (unpublished doctoral dissertation). Cornell University, New York, NY.

Jang, H. S., Lee, J. Y., Yoo, S. Y., Jung, U. J., \& Park, H. J. (2007). Word recognition for low-and high-pass filtered Korean CVC monosyllables in cochlear implant users. Audiology and Speech Research, 3(1), 58-63.

Ju, M. Y. (2005). The correlation between speech discriminations and speech intelligibilities of children with hearing aids and cochlear implants (unpublished master's thesis). Daegu University, Gyeongsan.

Kim, D. H. (2002). A study on speech discrimination ability between the hearing impaired children with hearing aids and cochlear implants (unpublished master's thesis). Daegu University, Gyeongsan.

Kim, M. J., JIn, S. R., \& Seok, D. I. (2006). The study on speech discrimination and intelligibility between children with conductive hearing loss and with cochlear implant. Journal of Speech and Hearing Disorders, 15(2), 4557.

Kim, U. J. (2009). A longitudinal case study on pervasive development of children with cochlear implant (unpublished master's thesis). Daegu University, Gyeongsan.

Lee, J. Y. (1999). A study of consonant perception and production by children with profound sensorineural hearing loss (unpublished master's thesis). Ewha Womans University, Seoul.

Lin, Y. S., Lu, H. P., Hung, S. C., \& Chang, C. P. (2009). Lexical tone identification and consonant recognition in acoustic simulations of cochlear implants. Acta Oto-Laryngologica, 129(6), 630-637.

Moon, H. R. (2003). Pitch and its characteristics of children with profound hearing impairment (unpublished master's thesis). Ewha Womans University, Seoul.

Oh, Y. J. (1999). Acoustic comparisons of vowel and plosive productions between the normal and the hearing-impaired children (unpublished master's thesis). Ewha Womans University, Seoul.

Owens, E. (1978). Consonant errors and remediation in sensorineural hearing loss. The Journal of Speech and Hearing Disorders, 43(3), 331347.

Roman, S., Canévet, G., Lorenzi, C., Triglia, J. M., \& Liégeois-Chauvel, C. (2004). Voice onset time encoding in patients with left and right cochlear implants. Neuroreport, 15(4), 601-605.

Shin, H. J. \& Seok, D. I. (2006). A VOT perceptual comparison of stop-consonant by normal and hearing-impaired children. Journal of Speech and Hearing Disorders, 15(3), 79-97.

Woo, J. S. (2006). Phonological awareness and reading comprehension in deaf children with cochlear implants (unpublished master's thesis). Yonsei University, Seoul.

Xu, L., Tsai, Y., \& Pfingst, B. E. (2002). Features of stimulation affecting tonal-speech perception: implications for cochlear prostheses. The Journal of the Acoustical Society of America, 112(1), 247-258. 